\title{
Biological Agent Certificate of Analysis Indicator
}

National Cancer Institute

\section{Source}

National Cancer Institute. Biological Agent Certificate of Analysis Indicator. NCI

Thesaurus. Code C158307.

An indication as to whether a certificate of analysis exists for the challenge agent. 